\title{
Agarwood (Aquilaria Crassna) Extracts Decrease High-protein High-fat Diet-induced Intestinal Putrefaction Toxins in Mice
}

Mamoru Kakino', Tsuyoshi Sugiyama², Hitomi Kunieda², Shigemi Tazawa ${ }^{3}$, Hiroe Maruyama ${ }^{3}$, Kazuhiro Tsuruma1, Yoko Araki ${ }^{3}$, Masamitsu Shimazawa ${ }^{1}$, Kenji Ichihara ${ }^{3}$, Hiroshi Mori ${ }^{2}$ and Hideaki Hara ${ }^{1 *}$

${ }^{1}$ Molecular Pharmacology, Department of Biofunctional Evaluation, Gifu Pharmaceutical University, Gifu 501-1196, Japan

${ }^{2}$ Microbiology, Department of Biopharmaceutical Science, Gifu Pharmaceutical University, Gifu 501-1196, Japan

${ }^{3}$ Nagara Research Center, API Co., Ltd., 692-3 Nagara, Gifu 502-0071, Japan

\begin{abstract}
Agarwood (Aquilaria spp.) is famous for its aromatic resin, but its leaves are also prized as a healthy tea in South East Asia. Previously, we reported that agarwood extract (Aquilaria sinensis and Aquilaria crassna) shows laxative effect via acetylcholine receptors in constipation model mice and rats. In the present study, we investigated the effects of agarwood (Aquilaria crassna) on intestinal toxins, such as indole derivatives and ammonium to investigate the enteral environment. Male mice received regimens of three types of food, CE-7 (normal diet), CE-2 (high-protein normal diet), and Quick Fat (high-protein high-fat diet). Extracts of agarwood (water extract of agarwood: WEA and ethanol extract of agarwood: EEA) were orally administered once daily for a week. We measured the contents of indole derivatives and ammonium in feces and also examined the Minimum Inhibitory Concentrations (MICs) of agarwood against nine strains of enterobacteria in vitro. As compared with CE-7, Quick Fat increased the contents of indoles and ammonium in fecal beads. Single administration and multiple administrations for 7 days of WEA at $1,000 \mathrm{mg} / \mathrm{kg} / \mathrm{day}$ decreased the contents of indoles and ammonium in fecal beads; on the other hand, multiple administrations of EEA decreased contents of indoles, but not those of ammonium. Interruption of administration abolished the effects of WEA and EEA. Quick Fat delayed carmine egestion in the digestive tract and administration of WEA and EEA accelerated the carmine egestion. Both WEA and EEA showed significant antimicrobial activity against some urease-positive bacteria, such as Staphylococcus aureus, Clostridium difficile, and Bacteroides spp. In conclusion, feeding with Quick Fat (high-protein high-fat diet) increased fecal-containing toxins and delayed carmine egestion in mice. Administrations of WEA and EEA decreased fecal-containing toxins and accelerated carmine egestion, and the decrement of fecal-containing toxins was abolished in response to interruption of the administration.
\end{abstract}

Keywords: Intestinal toxin; Intestinal putrifaction; Indole; Ammonium; Agarwood

Abbreviations: WEA: Water Extract of Agarwood; EEA: Ethanol Extract of Agarwood

\section{Introduction}

Agarwood (Aquilaria spp.) is well known for its aromatic resin. More than fifteen botanical species called "Agarwood" exist: Aquilaria apiculina, found in the Philippines, Aquilaria baillonil in Cambodia, Aquilaria baccarain in Indonesia, Aquilaria brachyantha in Malaysia, Aquilaria crassna in Thailand, Malaysia, and Cambodia, and Aquilaria sinensis in Taiwan. Their leaves are also cultivated as a healthy tea in South East Asian countries such as Viet Nam, Laos, and Thailand. We previously reported that ethanol extract of Aquilaria sinensis or Aquilaria crassna induces laxative effect on loperamide-induced constipation model mice and low-fiber-diet-induced constipation model rats; extract of agarwood increases the contractional tension of isolated jejunum and ileum of guinea pigs; and extract of agarwood accelerates carmine egestion delayed by low fiber-diet [1-3]. Subsequently, we identified mangiferin and genkuwanin-5-o-beta-glucoside as the major constituents that give rise to the laxative effects of Aquilaria sinensis and Aquilaria crassna.

Plant origin phenolic compounds (phenolics from tea, olives, and wine) have been reported to have antimicrobial activities against Escherichia coli, Salmonella, and Escherichia strains [4-9]. Agarwood is rich in various types of polyphenols [10-12]. Agarwood (Aquilaria sinensis) has also been reported to show antimicrobial activities against Escherichia coli, Staphylococcus aureus, and Bacillus subtilis [13]. Antimicrobial activities and laxative effect are closely associated with intestinal putrefaction, i.e. production of intestinal toxins, such as ammonium, indole, skatole, and p-cresol.

Ammonium is synthesized by urease-producing bacteria (Bacteroides fragilis, Proteus vulgaris, Eubacterium aerofaciens, Clostridium difficile, Clostridium perfringens, Peptostreptococcus prevotii, and Lactobacillus fermentum) in the large intestine. Ammonium synthesized in the intestines is absorbed into the portal vein and reaches the liver to be metabolized immediately, but hepatocirrhosis, hepatic function disorder, causes hyperammonemia. Hyperammonemia causes neurotoxicity and disruption of neurotransmission and is conventionally recognized as one of the sources of hepatic encephalopathy and Alzheimer's disease via attrition of reactive astrocyte and decrease of astroglia-derived glutathione [14-20]. Synthesized ammonium directly

*Corresponding author: Prof. Hideaki Hara, Molecular Pharmacology Department of Biofunctional Evaluation, Gifu Pharmaceutical University, 1-25-4 Daigaku-nishi, Gifu 501-1196, Japan, Tel : +81-58-230-8126; Fax: +81-58-2308126, E-mail: hidehara@gifu-pu.ac.jp

Received March 12, 2012; Accepted March 27, 2012; Published March 29, 2012 Citation: Kakino M, Sugiyama T, Kunieda H, Tazawa S, Maruyama $\mathrm{H}$, et al (2012) Agarwood (Aquilaria Crassna) Extracts Decrease High-protein Highfat Diet-induced Intestinal Putrefaction Toxins in Mice. Pharm Anal Acta 3:152. doi:10.4172/2153-2435.1000152

Copyright: ( 2012 Kakino M, et al. This is an open-access article distributed unde the terms of the Creative Commons Attribution License, which permits unrestricted use, distribution, and reproduction in any medium, provided the original author and source are credited. 
Citation: Kakino M, Sugiyama T, Kunieda H, Tazawa S, Maruyama H, et al. (2012) Agarwood (Aquilaria Crassna) Extracts Decrease High-protein High-fat Diet-induced Intestinal Putrefaction Toxins in Mice. Pharm Anal Acta 3:152. doi:10.4172/2153-2435.1000152

damages various organs including the gastrointestinal tract and induces arterioscleorosis, hypertensive, and autoimmune diseases.

Indolic compounds [(indole, skatole (3-methl indole), and IAA (indole 3-acetic acid)] are synthesized from tryptophan by indolepositive bacteria (Escherichia coli, Escherichia coli O-157, Proteus vulgaris, Clostridium perfringens, and Morganella morganii) mainly in the large intestine. Indolic compounds are absorbed into the portal vein and metabolized to the 3-indoxylsulfuric acid in the liver. 3-Indoxysulfuric acid is recognized as the most toxic compound to uremia patients and is also reported to inhibit osteoclast differentiation, bone-resorbing activity, smooth muscle proliferation, and HIFs(hypoxia-inducible transcription factors) induced erythropoietin production [21-23]. Indole, normal indole, is toxic for lactic acid bacterium strains [24].

Productions of intestinal toxins such as indole, ammonium, skatole (3-metyl indole), or $p$-cresol, are directly influenced by nutritional composition. Productions of indoles or $p$-cresol dominantly correlate with protein intake from the diet [25]. Especially, undigested protein from the stomach strongly increases indoles and $p$-cresol in urine via increment of metabolism by intestinal flora [26,27]. Furthermore, a high-fat and high-purine body diet increases division of intestinal epithelial cells and peeled epithelial cells provide tryptophan to intestinal flora to increase skatole, indole-derivative, formation $[28,29]$. All of the above indicate that a "western-style," high-fat high-protein diet may dominantly increase the contents of intestinal toxins in feces. But until now, few studies have shown us the appropriate animal model of deteriorated enteral environment induced by a western-style diet.

In this paper, we aimed to establish a western-style-diet-induced deteriorated enteral environment animal model and investigated the effect of Agarwood (Aquilaria crassna) on intestinal toxins produced by an established high-fat and high-protein diet.

\section{Materials and Methods}

\section{Materials}

Agarwood (Aquilaria crassna) leaves were supplied by API Co., Ltd. (Gifu, Japan). PBS, p-dimethylaminobenzaldehyde, ammonium chloride, and indole were purchased from Wako Pure Chemical Co., Ltd. (Osaka, Japan). Manganese sulfate, trisodium phosphate, trisodium citrate, and sulfuric acid were purchased from Nacarai Tesque Inc. (Kyoto, Japan). Ethanol, sodium hypochlorite, and sodium hydroxide were from Kishida Chemical Co. Ltd. (Tokyo, Japan). Carmine was purchased from Sigma-Aldrich Corp. (St Louis, MO, U.S.A.). Food pellets (CE-2, CE-7, and Quick Fat) were purchased from CLEA Japan, Inc. (Tokyo, Japan).

\section{Extraction procedures of water extract of agarwood (WEA) and ethanol extract of agarwood (EEA)}

WEA: Agarwood leaves (50 g) were chopped into small pieces and extracted with $\mathrm{H}_{2} \mathrm{O}$ at $95^{\circ} \mathrm{C}$ for $4 \mathrm{~h}$. We got 8.0-9.0 g of solid powder from the leaves every time. EEA: Agarwood leaves ( $50 \mathrm{~g}$ ) were chopped into small pieces and extracted with $60 \%$ ethanol $(1000 \mathrm{ml})$ at room temperature $\left(25.0^{\circ} \mathrm{C}\right)$ for $24 \mathrm{~h}$. We got $8.0-9.0 \mathrm{~g}$ of solid powder from leaves every time. The same lot as reference [30] is used in the present study.

\section{Animals}

Male ddY mice (6 weeks old) were purchased from Japan SLC
(Hamamatsu, Japan). The animals were housed at a controlled room temperature $\left(24.5-25.0^{\circ} \mathrm{C}\right)$ with a $12 / 12 \mathrm{~h}$ light/dark cycle. Food pellets (CE-2, CE-7, Quick Fat) and tap water were provided ad libitum. Feeding regimen was shown at supplemental table 2. All animal experiments were carried out according to the "Principles of Laboratory Animal Care" (NIH publication number 85-23, revised 1985) and "Guidelines of the Animal Investigation Committee of Gifu Pharmaceutical University". All experiments were approved by the Animal Investigation Committee of Gifu Pharmaceutical University.

\section{Bacterial species and strains}

Escherichia coli ATCC 25922, Bacteroides vulgatus GAI 0673, Bacteroides fragilis GAI 5524, Staphylococcus aureus ATCC 29213, Enterococcus faecalis GAI 03013, Clostridium difficile GAI 93004, Peponifhilus anaerobius GAI 5506, Bifidobacterium longum GAI 91362, and Bifidobacterium adolescentis GAI 06099 were used for determination of MIC of WEA and EEA.

\section{Quantification of indoles in stool beads}

Nine times weight of PBS was added to the stool beads (more than $50 \mathrm{mg}$ ) of mice and mixed very hard for 3-5 h until no lumps remain. The mixture was centrifuged at $5000 \mathrm{~g}$ for $15 \mathrm{~min}$; this reagent is "stool samples in PBS." p-Dimethylaminobenzaldehyde was added to the "blank luminescence reagent" (5.2\% (v/v) sulfuric acid / ethanol) at the rate of $1.47 \%(\mathrm{w} / \mathrm{v})$; this regent is "the positive luminescence reagent." Fifty $\mu$ l of "stool samples in PBS" were added to $300 \mu \mathrm{l}$ of "the positive luminescence reagent" and "blank luminescence reagent" respectively, then mixed very hard and stilled at room temperature for $30 \mathrm{~min}$. The mixture was centrifuged at $7500 \mathrm{rpm}$ for $10 \mathrm{~min}$ and optical density at $568 \mathrm{~nm}$ was measured. Standard curve was made with indole preparation. The concentrations of indole derivatives were determined as [(OD568 the positive luminescence reagent - OD568 reagent $)$, compensating the matrix effect.

\section{Quantification of ammonium in stool beads}

"Stool samples in PBS" for indole quantification was used for ammonium quantification. One hundred $\mu \mathrm{l}$ of stool samples in PBS and four hundred $\mu \mathrm{l}$ of PBS were put in the chilled centrifuging tube and gently mixed. Fifty $\mu \mathrm{l}$ of $3 \mathrm{mM}$ manganese sulfate, $1 \mathrm{ml}$ of phenolalkali solution $[6 \%(\mathrm{w} / \mathrm{v})$ phenol, $3 \%(\mathrm{w} / \mathrm{v})$ trisodium phosphate dodecahydrate, $3 \%(\mathrm{w} / \mathrm{v})$ ] trisodium citrate, and $0.3 \%(\mathrm{w} / \mathrm{v})$ EDTA], and $500 \mu \mathrm{l}$ of $0.12 \%$ available chlorine solution (sodium hypochlorite / $1 \mathrm{M}$ sodium hydroxide) were added to the chilled centrifuging tube. The tube was tightly sealed and boiled for 5 min mixing occasionally, then chilled in ice for $1 \mathrm{~min}$, and kept at room temperature for $20 \mathrm{~min}$, and then optical density at $635 \mathrm{~nm}$ was measured. Standard curve was made with ammonium chloride preparation.

\section{Measuring weight and number of stool beads}

The wet weights and numbers of stools were measured as the frequency and total wet weight for each mouse over $8 \mathrm{~h}$. WEA $(1,000 \mathrm{mg} / \mathrm{kg})$, EEA $(1,000 \mathrm{mg} / \mathrm{kg})$, or vehicle $(10 \%$ gum arabic) was administered orally, and the frequency and weight of stools were measured for each mouse during consecutive 2-h periods $(0-2 \mathrm{~h}, 2-4$ h, 4-6 h, 6-8 h). The samples were prepared at a concentration of 100 $\mathrm{mg} / \mathrm{ml}$ and administered $100 \mu \mathrm{l} / 10 \mathrm{~g}$. The mice were separated in small transparent cages $(11 \mathrm{~cm}$ height, $17.5 \mathrm{~cm}$ width, and $11 \mathrm{~cm}$ depth, one mouse to a cage). 
Citation: Kakino M, Sugiyama T, Kunieda H, Tazawa S, Maruyama H, et al. (2012) Agarwood (Aquilaria Crassna) Extracts Decrease High-protein High-fat Diet-induced Intestinal Putrefaction Toxins in Mice. Pharm Anal Acta 3:152. doi:10.4172/2153-2435.1000152

\section{Investigating the anti-microbial activities in vitro as Minimum Inhibitory Concentrations (MICs)}

Minimum Inhibitory Concentrations (MICs) of Agarwood extracts were determined by broth dilution techniques, according to the instructions of the Clinical and Laboratory Standards Institute (CLSI). Broth MIC testing was performed in 96-well microtiter trays. Mueller-Hinton broth (MHB, Becton Dickinson, Cockeysville, MD, USA) was used for cultures of Staphylococcus aureus and Escherichia coli, Brain Heart Infusion broth (BHI, Nissui, Tokyo, Japan) was for Enterococcus faecalis and Reinforced Clostridial Medium (RCM, Oxoid LTD., Basingstoke, Hampshire, England) was for Bacteroides vulgates, Bacteroides fragilis, Clostridium difficile, Peptostreptococcus anaerobius, Bifidobacterium longum, and Bifidobacterium adolescentis. For the cultivation of Bacteroides spp., C. difficile, P. anaerobius and Bifidobacterium spp., bacterial cultures were incubated under anaerobic condition in an anaerobic work-station, mini MACS (Don Whitley Scientific Led., West Yorkshire, England, UK). MIC values were obtained after incubation at $37^{\circ} \mathrm{C}$ for $24 \mathrm{~h}$ for cells of S. aureus, E. coli and Ent. faecalis or for $48 \mathrm{~h}$ for cells of Bacteroides spp., C. difficile, P. anaerobius and Bifidobacterium spp.. WEA and EEA were dissolved in 70\% ethanol before addition to MHB, BHI and RCM for MIC determinations.

\section{Statistical analysis}

Data are presented as mean \pm S.E.M. Statistical comparisons were made with the Student's $t$-test, the one-way ANOVA with Tukey's multiple comparison test, or two-way repeated measure analysis of variance (ANOVA) with $t$-test (JSTAT for Windows; Vector, Tokyo, Japan).

\section{Results}

\section{Effect of nutritional composition on body weights and stool parameters}

We first investigated the effect of nutritional composition on body weight, wet weight of stools, and frequency of stools. We kept mice with three types of diet, CE-7 (normal diet), CE-2 (high-protein normal diet), and Quick Fat (high-protein high-fat diet). CE-2 and Quick Fat contain 1.4 times more protein than CE-7, and Quick Fat contains 3.7 times more fat than CE-7 (Supplemental table 1). There were no major differences between the diets in contents of moisture, crude fiber, crude ash, and nitrogen-free extract. We recognized no difference between the above three groups in body weights of mice, wet weights of feces, and number of fecal beads (Supplemental Figure 1).

\section{Effect of nutritional composition on ammonium and indoles in stool beads}

We measured the contents of ammonium and indoles in fecal beads of the mice under regimens of three different diets (Supplemental Table 2A). As compared with CE-7, feces of mice under a regimen of CE-2 at the $8^{\text {th }}$ day showed a tendency to increase in the contents of ammonium (from $1068 \pm 330, \mathrm{n}=6$, to $1513 \pm 190 \mu \mathrm{g} / \mathrm{g}, \mathrm{n}=6$ ) and indoles (from 25.1 $\pm 2.5, \mathrm{n}=6$, to $28.3 \pm 1.6 \mathrm{mg} / \mathrm{g}, \mathrm{n}=6$ ) though not significant, and feces of mice under a regimen of Quick Fat showed a tendency to increase in ammonium contents (to $2101 \pm 414 \mu \mathrm{g} / \mathrm{g}, \mathrm{n}=6$ ) and showed significant increases in contents of indoles (to $51.7 \pm 3.2 \mathrm{mg} / \mathrm{g}, \mathrm{n}=6$ ) (Figure $1 \mathrm{~A}$ and $1 \mathrm{~B}$ ). As compared with CE-7, feces of mice under regimen of CE-2 at the $14^{\text {th }}$ day showed a tendency to increase in contents of ammonium (from $1045 \pm 57, \mathrm{n}=6$, to $1347 \pm 184 \mu \mathrm{g} / \mathrm{g}, \mathrm{n}=6$ ) and indoles (from

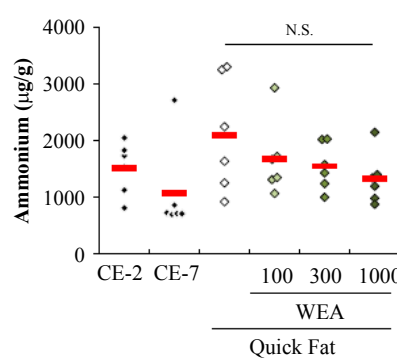

C

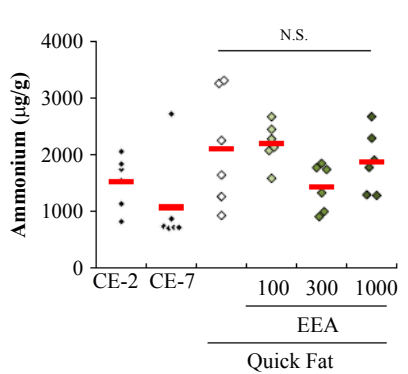

D
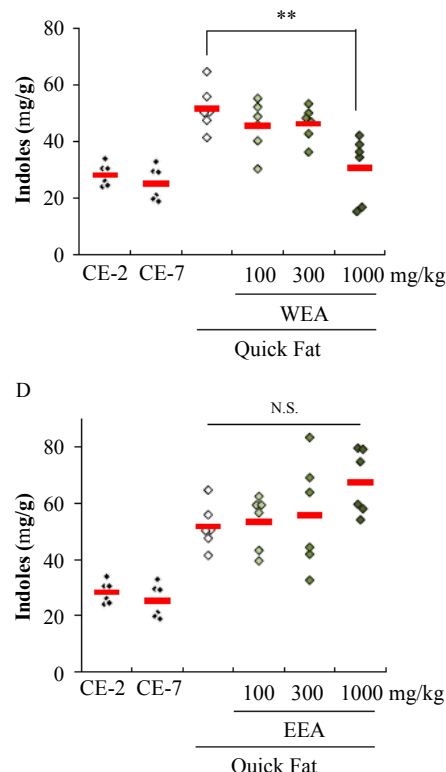

Figure 1: Effects of single administrations of WEA and EEA on mice under regimen of Quick Fat. Mice received a regimen of CE-2, CE-7, or Quick Fat. Then, WEA and EEA were orally administered to the mice under a regimen of Quick Fat at 100,300 , and $1,000 \mathrm{mg} / \mathrm{kg}$ according to the schedules shown in Supplemental Table 2B. We collected fresh fecal beads of the mice over $50 \mathrm{mg}$ at $8 \mathrm{~h}$ after the first administration of the samples and determined the contents of ammonium and indoles; (A, C): contents of ammonium, (B, D): contents of indoles. Determinations of indoles were executed on the same day as the collection of feces or the next day.

Average scores of each group were shown as square. $n=6,{ }^{* *}: p<0.01$ (oneway ANOVA and Tukey's multiple comparison test).

$23.8 \pm 2.1, \mathrm{n}=6$, to $33.2 \pm 2.4 \mathrm{mg} / \mathrm{g}, \mathrm{n}=6$ ) though not significant, and feces of Quick Fat-fed mice showed significant increases in contents of ammonium (to $3614 \pm 659 \mu \mathrm{g} / \mathrm{g}, \mathrm{n}=6$ ) and indoles (to $49.1 \pm 5.3 \mathrm{mg} / \mathrm{g}$, $\mathrm{n}=6$ ) (Figure $2 \mathrm{~A}$ and $2 \mathrm{~B}$ ).

\section{Effects of WEA and EEA on ammonium and indoles in stool} beads

We orally administered WEA and EEA at 100, 300, and 1,000 mg/ $\mathrm{kg}$ once per day for 7 days to the mice under a regimen of Quick Fat (Supplemental Table 2B). We measured the contents of ammonium and indoles in fecal beads of the mice after single administration and 7 days of multiple administrations. Single administration of WEA showed a tendency to decrease the contents of ammonium in feces from $2101 \pm$ 414 to $1673 \pm 271,1548 \pm 170$, and $1322 \pm 184 \mu \mathrm{g} / \mathrm{g}, \mathrm{n}=6$, at 100,300 , and $1000 \mathrm{mg} / \mathrm{kg}, \mathrm{n}=6$, respectively, and WEA significantly decreased the contents of indoles in feces from $51.7 \pm 3.2$ to $30.7 \pm 4.8 \mathrm{mg} / \mathrm{g}, \mathrm{n}=6$, at $1,000 \mathrm{mg} / \mathrm{kg}$ (Figure 1A and 1B). Dose-dependent decrease of indole was seen at the lower dose $(45.4 \pm 3.7$ and $46.3 \pm 2.5 \mathrm{mg} / \mathrm{g}, \mathrm{n}=6$, at 100 and 300, respectively). Single administration of EEA failed to affect the contents of ammonium and indoles in feces (Figure 1C and 1D). Seven days of multiple administrations of WEA dose-dependently showed a decrease of ammonium and indoles in feces (ammonium: from $3614 \pm$ 659 to $3046 \pm 636,2906 \pm 384$, and $1429 \pm 274 \mu \mathrm{g} / \mathrm{g}, \mathrm{n}=6$; indole: from $49.1 \pm 5.3$ to $57.2 \pm 4.8,34.8 \pm 5.8$, and $25.6 \pm 4.4 \mathrm{mg} / \mathrm{g}, \mathrm{n}=6)$ to the same level as those of CE-7 (ammonium: $1045 \pm 57 \mu \mathrm{g} / \mathrm{g}, \mathrm{n}=6$; indole: $23.8 \pm 2.1 \mathrm{mg} / \mathrm{g}, \mathrm{n}=6$ ) (Figure $2 \mathrm{~A}$ and $2 \mathrm{~B}$ ). Multiple administrations of EEA did not affect the contents of ammonium in feces, though the 
Citation: Kakino M, Sugiyama T, Kunieda H, Tazawa S, Maruyama H, et al. (2012) Agarwood (Aquilaria Crassna) Extracts Decrease High-protein High-fat Diet-induced Intestinal Putrefaction Toxins in Mice. Pharm Anal Acta 3:152. doi:10.4172/2153-2435.1000152

Page 4 of 7

contents of indoles decreased dose-dependently and significantly at $1,000 \mathrm{mg} / \mathrm{kg}$ (from $49.1 \pm 5.3$ to $24.4 \pm 1.1 \mathrm{mg} / \mathrm{g}, \mathrm{n}=6$ ).

\section{The effects of WEA and EEA on body weight and stool parameters}

We examined the body weight and wet weight and number of stools after 7 days of multiple administrations of the samples. WEA and EEA did not affect body weight at any dose and did not affect wet weight or number of stools at $1,000 \mathrm{mg} / \mathrm{kg}$ (Supplemental Figure 2).

\section{The effects of WEA and EEA on carmine egestion}

We examined carmine egestion to investigate activities of the digestive tract, which has a strong effect on intestinal toxin production. Carmine egestion was monitored every hour for $8 \mathrm{~h}$ after oral administration of carmine (10 mg/body). Carmine egestion is defined as the ingestion of carmine-containing feces over $30 \mathrm{mg}$ cumulatively. As compared with CE-7, feeding Quick Fat dominantly delayed the carmine egestion, though not significantly, and administrations of WEA and EEA at $1,000 \mathrm{mg} / \mathrm{kg}$ significantly accelerated the carmine egestion (Table 1).

\section{The effects of WEA and EEA administration interruption on decreased intestinal toxin}

After 7 days of multiple administrations of WEA and EEA, we aborted the administration and kept the mice for 7 days, and then we measured the contents of ammonium and indoles in fecal beads again. The significantly decreased contents of ammonium and indoles in fecal beads of the mice under daily administration of WEA (ammonium: $1937 \pm 244,1602 \pm 362$, and $2209 \pm 326 \mu \mathrm{g} / \mathrm{g}, \mathrm{n}=6$; indoles: $33.9 \pm$
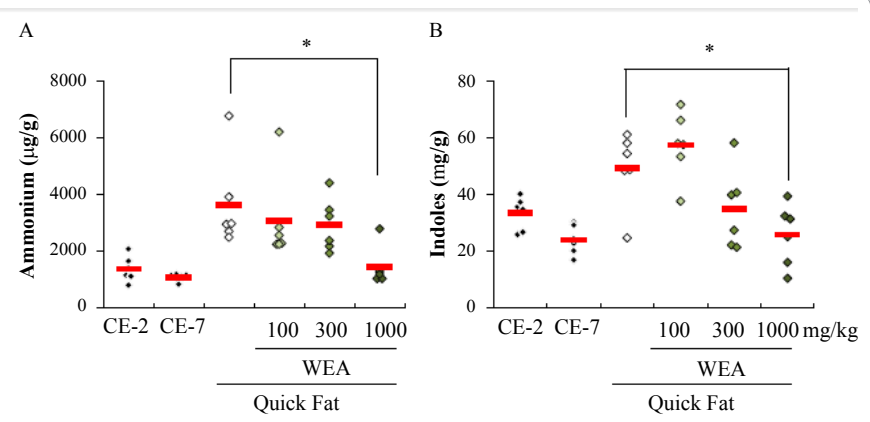

C

D

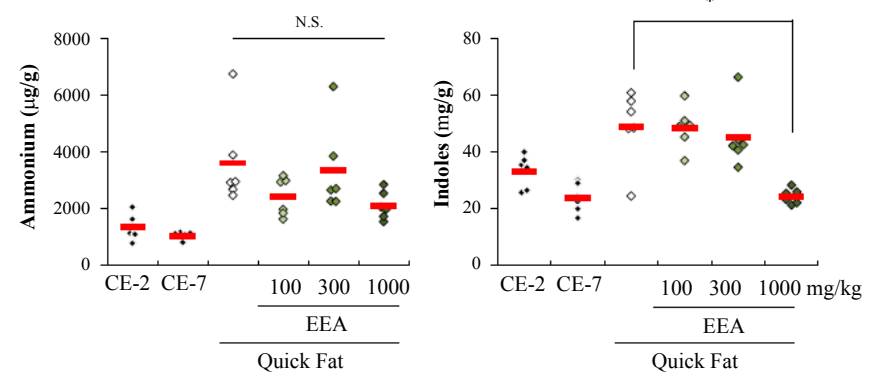

Figure 2: Effects of multiple administrations of WEA and EEA on mice under a regimen of Quick Fat. The experiments were performed as a continuation of Figure 1. We collected fresh fecal beads of the mice over 50 $\mathrm{mg}$ at $8 \mathrm{~h}$ after the seventh administration of the samples and determined the contents of ammonium and indoles; $(A, C)$ : contents of ammonium, $(B, D)$ : contents of indoles. Determinations of indoles were executed on the same day as the collection of feces or the next day.

Average scores of each group were shown as a square. $n=6,{ }^{*}: p<0.05$ (oneway ANOVA and Tukey's multiple comparison test)

\begin{tabular}{|c|c|c|c|c|c|}
\hline \multirow[b]{2}{*}{ Treatments } & \multirow[b]{2}{*}{$\mathrm{mg} / \mathrm{kg}$} & \multirow[b]{2}{*}{$\begin{array}{l}x^{2} \text { test vs. } \\
\text { Quick Fat }\end{array}$} & \multicolumn{3}{|l|}{ Scores } \\
\hline & & & $\begin{array}{l}\text { Fast } \\
(2-5 \mathrm{~h})\end{array}$ & $\begin{array}{l}\text { Medium } \\
(5-8 \mathrm{~h})\end{array}$ & $\begin{array}{l}\text { Slow } \\
\text { (over } \\
8 \mathrm{~h} \text { ) }\end{array}$ \\
\hline CE-7 & & $p=0.148$ & 3 & 4 & 1 \\
\hline Quick Fat & & & 0 & 7 & 1 \\
\hline WEA (Quick Fat) & 1000 & $p=0.022^{*}$ & 5 & 3 & 0 \\
\hline EEA (Quick Fat) & 1000 & $p=0.008^{* *}$ & 6 & 2 & 0 \\
\hline \multicolumn{3}{|c|}{ WEA: water extract of agarwood } & & & \\
\hline \multicolumn{3}{|c|}{ EEA: ethanol extract of agarwood } & & & \\
\hline
\end{tabular}

Mice received a regimen of CE-7 or Quick Fat for a week. A vehicle $(10 \%$ gum arabic), WEA, and EEA at $1,000 \mathrm{mg} / \mathrm{kg}$ were orally administered to the mice. Carmine (10 mg/body) was orally administered to the mice just before administration of the samples, and then the weights of carmine-containing feces were measured during consecutive 1-h periods over $8 \mathrm{~h}$. Carmine egestion was determined as egestion of carmine-containing fecal beads over $30 \mathrm{mg}$. The carmine egestion point was classified into three groups; Fast: egested in $2-5 \mathrm{~h}$, Medium: egested in 5-8 h, Slow: not egested in $8 \mathrm{~h}$ after administration $\mathrm{n}=8$.

Table 1: Effects of WEA and EEA on carmine egestion in mice.

$2.4,33.1 \pm 1.3$, and $39.2 \pm 4.2 \mathrm{mg} / \mathrm{g}, \mathrm{n}=6$; at 100,300 , and $1,000 \mathrm{mg} /$ $\mathrm{kg}$ ) were increased to the same levels as the vehicle-administered mice (ammonium: $2010 \pm 85 \mu \mathrm{g} / \mathrm{g}, \mathrm{n}=6$; indoles: $39.4 \pm 1.7 \mathrm{mg} / \mathrm{g}, \mathrm{n}=6$ ) after interruption of administration (Figure $3 \mathrm{~A}$ and $\mathrm{B}$ ). The significantly decreased contents of the indoles of mice under daily administration of EEA $(45.7 \pm 2.6,40.2 \pm 1.7$, and $36.0 \pm 1.9 \mathrm{mg} / \mathrm{g}$; at 100,300 , and 1,000 $\mathrm{mg} / \mathrm{kg}, \mathrm{n}=6$ ) were also increased to a level of the vehicle-administered mice $(39.4 \pm 1.7 \mathrm{mg} / \mathrm{g}, \mathrm{n}=6)$ after interruption of administration (Figure 3D).

\section{The antimicrobial activities of WEA and EEA in vitro as Minimum Inhibitory Concentrations (MICs)}

Both WEA and EEA showed significant antimicrobial activities against gram-positive and gram-negative bacteria, such as Bacteroides vulgas $(\mathrm{MIC}=8 \mathrm{mg} / \mathrm{ml})$, Bacteroides longum $(\mathrm{MIC}=8 \mathrm{mg} / \mathrm{ml})$, Staphylococcus aureus $(\mathrm{MIC}=4)$, Clostridium difficile ( $\mathrm{MIC}=8$ and $4 \mathrm{mg} / \mathrm{ml}$ [WEA and EEA, respectively]), and Peptostreptococcus anaerobius ( $\mathrm{MIC}=4 \mathrm{mg} / \mathrm{ml}$ ) (Table 2). On the other hand, neither WEA nor EEA showed antimicrobial activities against Eecherichia coli, Enterococcus faecalis, or Bifidobacterium spp. (MICs $>8 \mathrm{mg} / \mathrm{ml}$ ). Similar MIC values were obtained in two independent experiments performed in duplicate.

\section{Discussion}

In the present study, we first verified that Quick Fat, a commercial diet developed to research type 2 diabetes, deteriorates the enteral environment, as does a western-style diet. A regimen of Quick Fat ordinarily takes more than 14 weeks to induce type 2 diabetes, though blood cholesterol increases at the early stage, less than 15 days, of a regimen [31]. In contrast, our study shows that a regimen of Quick Fat over only 1 week significantly increased the contents of indoles as compared with CE-7 (Figure 1B, 2B, and 3B), while the contents of ammonium significantly increased with a regimen of Quick Fat over 2 weeks (Figure 2B and 3B). We kept mice with Quick Fat for 3 weeks, and then we recognized that a regimen of Quick Fat for only 3 weeks did not affect body weight, indicating that no mice are obese (Supplemental Figure 1A). A four weeks' regimen of Quick Fat did not affect wet weight or number of stools, indicating that no mice are suffered from constipation (Supplemental Figures $1 \mathrm{~B}$ and 1C). A regimen of CE-2 
Citation: Kakino M, Sugiyama T, Kunieda H, Tazawa S, Maruyama H, et al. (2012) Agarwood (Aquilaria Crassna) Extracts Decrease High-protein High-fat Diet-induced Intestinal Putrefaction Toxins in Mice. Pharm Anal Acta 3:152. doi:10.4172/2153-2435.1000152

Page 5 of 7

over 1 week, high-protein diet, showed a tendency to increase the contents of ammonium and indoles as compared with CE-7 (Figures 1,2 , and 3), but not significantly. All of the above indicate that highprotein and high-fat contents act additively to increase the contents of ammonium and indoles in fecal beads of mice. A regimen of high-fat diet grows Clostridium perfringens, a bacterial strain that elaborates both the indoles and ammonium, particularly when sodium cholate, an ionic-emulsifying agent secreted into the bile from the liver, is added [32]. It makes sense that protein contained in the diet provides the basic ingredients of ammonium and indoles; on the other hand, fat in the diet grows ammonium- or indole-positive germs in the gastrointestinal tract. From these points of view, we judged that a regimen of Quick Fat as compared with CE-7 is useful animal model for a deteriorated enteral environment model, which is available for research of intestinal toxins apart from constipation.

We administered WEA and EEA at 100, 300, and 1,000 mg/kg once per day for 7 days to the mice under a regimen of Quick Fat. A single administration of WEA at $1,000 \mathrm{mg} / \mathrm{kg}$ has significantly decreased indoles, but not EEA (Figure 1B and 1D). On the other hand, single administrations of WEA and EEA failed to decrease ammonium significantly, though WEA showed such a tendency (Figure 1A and 1C). Single administrations of WEA and EEA significantly accelerated carmine egestion under a regimen of Quick Fat (Table 1). The quantities of intestinal putrefactions are estimated to bear a proportionate relationship between total retention times of contents in gastrointestinal tract. But the failure of EEA to decrease ammonium and indoles is unexplainable via acute acceleration of the gastrointestinal contents.

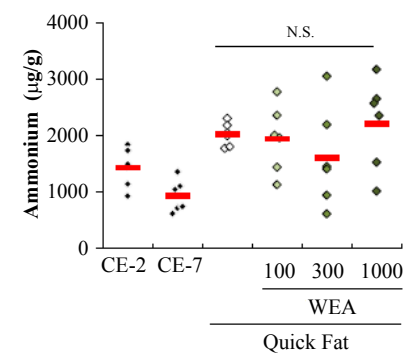

$\mathrm{C}$
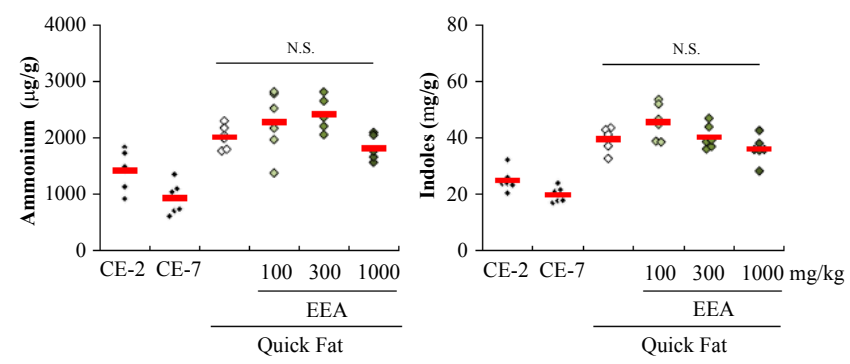

Figure 3: Effect of seven days-interruption of WEA and EEA administration on mice under a regimen of Quick Fat. The experiments were performed as a continuation of Figure 2. We aborted administration of the samples in all groups after the seventh administration, and then we collected feces of the mice over $50 \mathrm{mg}$ one week later and determined the contents of ammonium and indoles; $(A, C)$ : contents of ammonium, $(B, D)$ : contents of indoles. Determinations of indoles were executed on the same day as the collection of feces or the next day.

Average scores of each group were shown as a square. $n=6$, N.S.: $p>0.05$ (one-way ANOVA and Tukey's multiple comparison test).

\begin{tabular}{|l|c|c|c|}
\hline & \multicolumn{2}{|c|}{ MICs of Agarwood extracts (mg/ml) } \\
\hline & WEA & EEA & Ammoniagenesis* \\
\hline G (-) Bacteria & & & \\
\hline Escherichia coli & $>8$ & $>8$ & $+[37,38]$ \\
\hline Bacteroides vulgatus & 8 & 8 & $+[38]$ \\
\hline Bacteroides fragilis & 8 & 8 & $+[38]$ \\
\hline G (+) Bacteria & & & $+[37]$ \\
\hline Staphylococcus aureus & 4 & 4 & $+[38]$ \\
\hline Clostoridium difficile & 8 & 4 & $++[39-41]$ \\
\hline Peptostreptococcus anaerobius & 4 & 4 & $+[42]$ \\
\hline Enterococcus faecalis & $>8$ & $>8$ & $-[39]$ \\
\hline Bifidobacterium longtum & $>8$ & $>8$ & $-[39]$ \\
\hline Bifidobacterium adolescentis & $>8$ & $>8$ & + ( \\
\hline
\end{tabular}

*Ammoniagenesis was graded according to the previous reports; ++: strong positive, +: positive, -: negative

Table 2: Minimum inhibitory concentrations (MICs) of WEA and EEA

Multiple administrations of WEA at $1,000 \mathrm{mg} / \mathrm{kg}$ significantly decreased the contents of ammonium and indoles (Figure 2A and 2B). On the other hand, EEA at $1,000 \mathrm{mg} / \mathrm{kg}$ significantly decreased the contents of indoles, but not ammonium (Figure 2C and 2D). Multiple administrations of WEA and EEA did not affect the wet weight of stools or number of stools (Supplemental Figure 2B and 2C), indicating that ammonium and indole concentrations, $\mathrm{mg} / \mathrm{g}$, in fecal beads are proportional to their production quantities, $g$, in the gastrointestinal tract of a mouse. Considering the result that single administrations of WEA and EEA did not affect the contents of ammonium, ammonium might be insusceptible to gastrointestinal transit time and be influenced by another predominant factor, such as microbial environment.

We then investigated the antimicrobial activities of WEA and EEA against urease-positive and -negative enterobacteria. Both WEA and EEA showed antimicrobial activities on some urease-positive enterobacteria at 4 to $8 \mathrm{mg} / \mathrm{ml}$ (Table 2), at lower concentrations than the administration solution in the animal experiments $(10$ to $100 \mathrm{mg} / \mathrm{ml}$ ) we presented at Figures 2 and 3. On the other hand, WEA or EEA did not affect Escherichia coli and lactic acid bacteria (Enterococcus faecalis, Bifidobacterium longum, and Bifidobacterium adolescentis). Previous report shows that some tea polyphenol show bactericidal activities on Staphylococcus aureus and Clostridium perfringens but not on Escherichia coli and Bifidobacteria [33]. On the other hand, Escherichia coli and Bifidobacteria is susceptible to $\mathrm{pH}$ of gastrointestinal tract [34], not to botanical polyphenols. The difference of susceptibility to antibacterial effect of WEA and EEA is depending on susceptibility to botanical polyphenols. Interestingly, among the nine strains we examined in the present study, only Enterococcus faecalis and Escherichia coli are indole-producing bacteria [35,36], and neither strain is susceptible to the antimicrobial activities of WEA or EEA (Table 2). Urease, an ammonia genesis enzyme, is active mainly at the mucosa of the small intestine (mammalian-derived urease) and large bowel flora (bacteria-derived urease), meaning that a half of ammonium production in the intestine belongs to the metabolism of mammalians. Indole production in the intestine depends mainly on indole-positive bacteria. Difference of susceptibility to WEA between indoles and ammonium may depend on the producing enterobacteria 
Citation: Kakino M, Sugiyama T, Kunieda H, Tazawa S, Maruyama H, et al. (2012) Agarwood (Aquilaria Crassna) Extracts Decrease High-protein High-fat Diet-induced Intestinal Putrefaction Toxins in Mice. Pharm Anal Acta 3:152. doi:10.4172/2153-2435.1000152

Page 6 of 7

and derivation mechanisms. These findings indicate that WEA may interfere with the total span of indole production via shortening the retention time of gastrointestinal contents at a short span, and interfere with the rate of ammonium production via antimicrobial activities against urease-positive enterobacteria.

At the end of a set of regimens, we aborted the administrations of WEA and EEA to verify the hypothesis stating the decrement of indole or ammonium requires continuous administration. A oneweek cessation of administration abolished the decrement of indole and ammonium (Figure 3), meaning that the decreased production quantities during the administration regimens increased to the same level as the vehicle groups after cessation of administration. This result indicates that we need continuous administrations of WEA or EEA to remedy the enteral environment deteriorated by a western-style diet.

In summary, a comparison between CE-7 and Quick Fat is useful to research western-style-diet-induced deteriorated enteral environments. Quick Fat increased the concentrations of ammonium and indoles in fecal beads, which is proportional to production quantities, without inducing constipation or increment of body weight. Single administrations of WEA and EEA significantly accelerated carmine egestion. Single administrations of WEA significantly decreased the production quantities of indoles in gastrointestinal tract and multiple administrations of WEA significantly decreased the production quantities of ammonium and indoles. WEA and EEA showed significant antimicrobial activities against some urease-positive enterobacteria, but not indole-positive enterobacteria. The series of decrements of intestinal putrefaction require continuous administrations.

\section{Acknowledgement}

This work was supported by the 1 Risk-Taking Funds for Technology Development from the Japan Science and 12 Technology Agency (Science Plaza, Tokyo).

\section{References}

1. Hara H, Ise $\mathrm{Y}$, Morimoto $\mathrm{N}$, Shimazawa M, Ichihashi K, et al. (2008) Laxative effect of agarwood leaves and its mechanism. Biosci Biotechnol Biochem72: 335-345

2. Kakino M, Izuta H, Ito T, Tsuruma K, Araki Y, et al. (2010) Agarwood induced laxative effects via acetylcholine receptors on loperamide-induced constipation in mice. Biosci Biotechnol Biochem 74: 1550-1555.

3. Kakino M, Tazawa S, Maruyama H, Tsuruma K, Araki Y, et al. (2010) Laxative effects of agarwood on low-fiber diet-induced constipation in rats. BMC Complement Altern Med 10: 68

4. Howell AB, Vorsa N, Der Marderosian A, Foo LY (1998) Inhibition of the adherence of P-fimbriated Escherichia coli to uroepithelial-cell surfaces by proanthocyanidin extracts from cranberries. N Engl J Med 339: 1085-1086.

5. Howell AB (2002) Cranberry proanthocyanidins and the maintenance of urinary tract health. Crit Rev Food Sci Nutr 42: 273-278.

6. Adlercreutz H (2002) Phyto-oestrogens and cancer. Lancet Oncol 3: 364-373.

7. Puupponen-Pimiä R, Nohynek L, Meier C, Kähkönen M, Heinonen M, et al. (2001) Antimicrobial properties of phenolic compounds from berries. J Appl Microbiol 90: 494-507.

8. Rowland I, Wiseman H, Sanders T, Adlercreutz H, Bowey E (1999) Metabolism of oestrogens and phytoestrogens: role of the gut microflora. Biochem Soc Trans 27: 304-308.

9. Sharon N, Ofek I (2002) Fighting infectious diseases with inhibitors of microbial adhesion to host tissues. Crit Rev Food Sci Nutr 42: 267-272.

10. Takemoto H, Ito M, Shiraki T, Yagura T, Honda G (2008) Sedative effects of vapor inhalation of agarwood oil and spikenard extract and identification of their active components. J Nat Med 62: 41-46.

11. Konishi T, Konoshima T, Shimada Y, Kiyosawa S (2002) Six new 2-(2-phenylethyl)chromones from Agarwood. Chem Pharm Bull (Tokyo) 50 419-422.

12. Yagura T, Ito M, Kiuchi F, Honda G, Shimada Y (2003) Four new 2-(2-phenylethyl) chromone derivatives from withered wood of Aquilaria sinensis. Chem Pharm Bull (Tokyo) 51: 560-564.

13. Cui JL, Guo SX, Xiao PG (2011) Antitumor and antimicrobial activities of endophytic fungi from medicinal parts of Aquilaria sinensis. J Zhejiang Univ Sci B 12: 385-392.

14. Drewes LR, Leino RL (1985) Neuron-specific mitochondrial degeneration induced by hyperammonemia and octanoic acidemia. Brain Res 340: 211-218.

15. Lai JC, Cooper AJ (1991) Neurotoxicity of ammonia and fatty acids: differentia inhibition of mitochondrial dehydrogenases by ammonia and fatty acyl coenzyme A derivatives. Neurochem Res 16: 795-803.

16. Gutnick MJ (1976) Letter: Hyperammonemia and hepatic encephalopathy in the dog. J Am Vet Med Assoc 168: 3-4.

17. Fisman M, Gordon B, Feleki V, Helmes E, Appell J, et al. (1985) Hyperammonemia in Alzheimer's disease. Am J Psychiatry 142: 71-73.

18. Hawkins RA, Mans AM (1993) Brain metabolism in hepatic encephalopathy and hyperammonemia. Adv Exp Med Biol 341: 13-19.

19. Koo H, Roessmann U (1988) Astrocyte response to perinatal liver disease, hyperammonemia, and hyperbilirubinemia: an immunohistochemical study. Pediatr Pathol 8: 301-311.

20. Hilgier W, Wegrzynowicz M, Ruszkiewicz J, Oja SS, Saransaari P, et al. (2010) Direct exposure to ammonia and hyperammonemia increase the extracellular accumulation and degradation of astroglia-derived glutathione in the rat prefrontal cortex. Toxicol Sci 117: 163-168.

21. Mozar A, Louvet L, Godin C, Mentaverri R, Brazier M, et al. (2011) Indoxyl sulphate inhibits osteoclast differentiation and function. Nephrol Dial Transplant.

22. Mozar A, Louvet L, Morlière P, Godin C, Boudot C, et al. (2011) Uremic toxin indoxyl sulfate inhibits human vascular smooth muscle cell proliferation. Ther Apher Dial 15: 135-139.

23. Chiang CK, Tanaka T, Inagi R, Fujita T, Nangaku M (2011) Indoxyl sulfate a representative uremic toxin, suppresses erythropoietin production in a HIFdependent manner. Lab Invest 91: 1564-1571.

24. Nowak A, Libudzisz Z (2006) Influence of phenol, p-cresol and indole on growth and survival of intestinal lactic acid bacteria. Anaerobe 12: 80-84.

25. Geypens B, Claus D, Evenepoel P, Hiele M, Maes B, et al. (1997) Influence of dietary protein supplements on the formation of bacterial metabolites in the colon. Gut 41: 70-76.

26. Evenepoel P, Claus D, Geypens B, Maes B, Hiele M, et al. (1998) Evidence for impaired assimilation and increased colonic fermentation of protein, related to gastric acid suppression therapy. Aliment Pharmacol Ther 12: 1011-1019.

27. Rosell JM (1929) Studies in Digestive Pathology: II. The Mechanism of Fermentation and Putrefaction in the Intestines. Can Med Assoc J 21: 161-168.

28. Raab S, Leiser R, Kemmer H, Claus R (1998) Effects of energy and purines in the diet on proliferation, differentiation, and apoptosis in the small intestine of the pig. Metabolism 47: 1105-1111.

29. Claus R, Raab S (1999) Influences on skatole formation from tryptophan in the pig colon. Adv Exp Med Biol 467: 679-684.

30. Tetsuro Ito MK, Shigemi Tazawa, Masayoshi Oyama, Hiroe Maruyama, Yoko Araki, et al. (2012) Identification of phenolic compounds in Aquilaria crasna leaves via liquid chromatography-electrospray ionization mass spectroscopy. Food Science and Technology Research.

31. Sampathkumar MT, Kasetti RB, Nabi SA, Sudarshan PR, Swapna S, et al (2011) Antihyperlipidemic and antiatherogenic activities of Terminalia pallida Linn. fruits in high fat diet-induced hyperlipidemic rats. J Pharm Bioallied Sci 3: 449-452.

32. Graber CD, O'Neal RM, Rabin ER (1965) Effect of High Fat Diets on Intestinal Microflora and Serum Cholesterol in Rats. J Bacteriol 89:47-51.

33. Hara H, Orita N, Hatano S, Ichikawa H, Hara Y, et al. (1994) Effect of tea polyphenols on fecal flora and fecal metabolic products of pigs. J Vet Med Sci 57: 45-49. 
Citation: Kakino M, Sugiyama T, Kunieda H, Tazawa S, Maruyama H, et al. (2012) Agarwood (Aquilaria Crassna) Extracts Decrease High-protein High-fat Diet-induced Intestinal Putrefaction Toxins in Mice. Pharm Anal Acta 3:152. doi:10.4172/2153-2435.1000152

34. Gray JD, Shiner M (1967) Influence of gastric $\mathrm{pH}$ on gastric and jejunal flora. Gut 8: 574-581.

35. Lombard GL, Dowell VR Jr (1983) Comparison of three reagents for detecting indole production by anaerobic bacteria in microtest systems. J Clin Microbio 18: 609-613.

36. Romanik M, Martirosian G, Wojciechowska-Wieja A, Cieślik K, Kaźmierczak W (2007) [Co-occurence of indol-producing bacterial strains in the vagina of women infected with Chlamydia trachomatis]. Ginekol Pol 78: 611-615.

37. Broomfield RJ, Morgan SD, Khan A, Stickler DJ (2009) Crystalline bacteria biofilm formation on urinary catheters by urease-producing urinary tract pathogens: a simple method of control. J Med Microbiol 58: 1367-1375.

38. Ito Y, Nakamura T, Saito K, Moriwaki H, Muto Y, et al. (1992) Pathophysiological role of intestinal flora in the development of hepatic encephalopathy, with special reference to floral alterations induced by antimicrobial agents. Microb Ecol Health Dis 5: 1-13.

39. Suzuki K, Benno Y, Mitsuoka T, Takebe S, Kobashi K, et al. (1979) Ureaseproducing species of intestinal anaerobes and their activities. Appl Environ Microbiol 37: 379-382.

40. Flythe MD (2009) The antimicrobial effects of hops (Humulus lupulus L.) on ruminal hyper ammonia-producing bacteria. Lett Appl Microbiol 48: 712-717.

41. Paster BJ, Russell JB, Yang CM, Chow JM, Woese CR, et al. (1993) Phylogeny of the ammonia-producing ruminal bacteria Peptostreptococcus anaerobius, Clostridium sticklandii, and Clostridium aminophilum sp. nov. Int J Syst Bacteriol 43: 107-110.

42. Lauková A, Koniarová I (1995) Survey of urease activity in ruminal bacteria isolated from domestic and wild ruminants. Microbios 84: 7-11. 